Send your letters to the Editor,

British Dental Journal,

64 Wimpole Street

London

W1G 8YS

Email bdj@bda.org

Priority will be given to letters less than 500 words long.

Authors must sign the letter, which

may be edited for reasons of space.

\section{FALLING BELOW}

Sir, I would like to thank Dr Cockcroft for his response to my letter HTM 01-05 revision (BDJ 2009; 207: 144-145) where it seems we can at least agree that the quality of evidence used in one aspect of HTM 01-05 may have fallen below that which the DH usually employs. ${ }^{1}$

I know Dr Cockcroft feels as I do that 'It is essential that guidance from DH is, where possible, based on robust evidence', as he recently stated in a CD0 newsletter. ${ }^{2}$

As if to reinforce to us all how critical it is to get centralised guidance right before its imposition, Dr Cockcroft explains the consequences of not following such newly created guidance to the letter, bringing down the wrath of legislation in NHS regulations, the new Care Quality Commission and even Fitness to Practise GDC disciplinary procedures to bear on anyone who dare vary or question such guidance!

It may be of course that the unavailable 60 plus references alluded to in Dr Cockcroft's reply* meet the highest evidence standards of Cochrane level 4 or even level $3 \mathrm{GRADE}^{3}$ quality, so I am mystified as to why these have never been produced for public or professional scrutiny. Indeed if they are so reliable/compelling that would be reassuring. If, however, they are at the lowest GRADE 1 of evidence (expert opinion and poorly controlled trials) then surely one must question whether such extensive, expensive and potentially retrograde changes purporting to be 'best practice', should be made compulsory before any such high-quality evidence is further commissioned and evaluated.

Given the existing publicly available evidence that vCJD deaths have only totalled 167 over 20 years, are in steep decline since their peak in 2000 and it is predicted there will only be one or two new vCJD cases occurring per year now, one must ask why then this HTM 01-05 disproportionate response when NO cases have ever been associated with dentistry ${ }^{4}$

Any risk assessment should take into account 'Failure Modes' and 'Effects Analysis' (FMEA), where failure modes are any defects in a process, design or item (eg: WDs) and effect analysis looks at the effects of those failures. ${ }^{5}$ Immediately the published literature would raise FMEA concerns where proposed HTM 01-05 'best practice' methods using hightemperature washer disinfectors (WD) leave significant amounts of proteins on sterilised instruments consistently. ${ }^{6-10}$

Thus for such decontamination stages pre-autoclaving, shouldn't emphasis be on ensuring existing protocols are used routinely, ${ }^{11}$ physical scrubbing, ${ }^{12}$ ordinary washers operating at lower temperatures that don't bake on proteins, ${ }^{13}$ or/ and an ultrasonic bath stages ${ }^{14}$ as used currently, which have lower FMEA risks and provide safer, superior and more evidence-based results than those about to be enforced in HTM 01-05 best practice?

I can do no better than quote the DH's own report in $2006^{15}$ looking at current WDs/autoclaving systems which states, '...the high levels of retained protein burden after decontamination through typical NHS systems is itself a matter for concern'.

We need scientific validation first, otherwise printer-validation on hightemperature WDs may simply prove we have left 'high levels of retained protein burden' on all our dental instruments instead - I can just imagine patient consent to that not being very popular!
I hope therefore that Dr Cockcroft and the wider $B D J$ readership can be reassured that my motives in asking for urgent evidence-based revision now, before the current HTM 01-05 is printed then imposed, are honourable. Thus my request to help ensure this important new guidance is all that it can be, in the wider public interest, still stands.

T. Kilcoyne

"Editor-in-Chief's note: Dr Cockcroft has now provided the BDA with a list of 90 references in relation to HTM 01-05 but without Grading, which he has noted is to follow soon. In the meantime the BDA's Health and Science Committee is beginning the not inconsiderable task of analysing the references provided.

1. Cockcroft B. A legislative requirement. Br Dent J 2009; 207: 303.

2. Department of Health. CDO update publication. p 8. June 2008.

3. Higgins J P T, Green S. Cochrane Handbook for Systematic Reviews of Interventions. pp 360-367. 2008

4. Department of Health. 16th Annual Report 2007 of The National CJD Surveillance Unit. pp 4-28.

5. Stamatis D H. Failure mode and effect analyis: FMEA from theory to execution. p 12. Amer Society for Quality, 1995.

6. Lipscomb I P, Sihota A K Keevil C W. Comparative study of surgical instruments from sterile-service departments for presence of residual gram negative endotoxin and proteinaceous deposits. J Clin Microbio/ 2006; 44: 3728-3733.

7. Baxter R L, Baxter H C, Campbell G A, Grant K et al. Quantitative analysis of residual protein contamination on reprocessed surgical instruments. J Hosp Infect 2006; 63: 439-444.

8. Murdoch H, Taylor D, Dickinson J, Walker J T et al. Surface decontamination of surgical instruments: an ongoing dilemma. J Hosp Infect 2006; 63: 432-438.

9. Lipscomb I P, Sihota A K, Botham M, Harris K et $a l$. Rapid method for the sensitive detection of protein contamination on surgical instruments. $J$ Hosp Infect 2006; 62: 141-148.

10. Department of Health. Assessing the risk of VCJD transmission via surgery: an interim review. London: Economic, Statistics and Operational Research, June 2005

11. Bagg J, Smith A J, Hurrell D, McHugh S et al. Presterilisation cleaning of reusable instruments in general dental practice. Br Dent J 2007; 202: E22, discussion 501-502. 
12. Wu X, YuX. Influence of usage history, instrument complexity and different cleaning procedures on the cleaning of blood-contaminated dental surgical instruments. Infect Control Hosp Epidemiol 2009; 30: 702-704.

13. Ebner W, Eitel A, Scherrer M, Daschner F D. Can household dishwashers be used to disinfect medical equipment? J Hosp Infect 2000; 45: 155-159.

14. Perakaki K, Mellor A C, Qualtrough A J. Comparison of an ultrasonic cleaner and a washer disinfector in the cleaning of endodontic files. J Hosp Infect 2007; 67: 355-359.

15. Department of Health. Engineering and Science Advisory Committee into the Decontamination of Surgical Instruments Including Prion Removal. London, 2006.

DOI: 10.1038/sj.bdj.1085

\section{JUMPING THE GUN}

Sir, I was surprised to read in the letter from V. Ballal entitled Oil therapy (BDJ 2009; 207: 193) that the literature has reported that swishing sunflower oil around the mouth for 15 minutes a day can 'effectively treat ... meningitis, heart and kidney disorders, women's hormonal disorders, and chronic diseases like cancer, AIDS etc.' However, no references were provided and a cursory search of the literature found only studies examining oil pulling as a means of managing oral bacteria. The claims of effectiveness against a long list of unrelated conditions, as well as the references to toxins, healing 'all organs simultaneously' and an unknown mechanism, are all reminiscent of the language used to promote unproven or disproven alternative remedies.

Oil pulling may or may not prove a useful technique, but for traditional remedies to enter the folds of evidencebased medicine it is important to investigate any real effects they may have without being distracted by illusory effects ascribed to them by their advocates. Without strong evidence that oil pulling has an effect beyond those of placebo and a thorough oral rinse, the suggested research to discover the source of this effect would seem to be jumping the gun.

\section{A. Taylor By email DOI: 10.1038/sj.bdj.1086}

\section{NOT RECOMMENDED}

Sir, with reference to the letter Oil therapy published in your journal (BDJ 2009; 207: 193) we would like to share our experience on this.

We treated a case of severe inflammatory gingival enlargement in a 48-

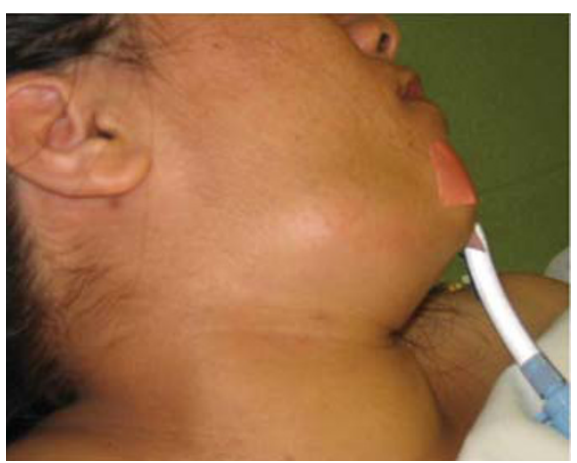

Fig. 1 Non-erythematous, non-tender lesion on right lower border of mandible

year-old female. She was suffering from swollen and bleeding gums for which was suggested, as treatment, oil pulling (OP) using refined sunflower oil by a friend who was also practising OP. She had performed OP for three months and had observed that her problem was worsening. When we saw her, we noticed generalised gingival enlargement, multiple false deep periodontal pockets and mild sub-gingival calculus deposits. She was healthy and was not taking any kind of medication. We suggested she stop OP and reviewed her case after three weeks; her gingival inflammation had substantially reduced. Following this she was treated with conventional periodontal therapy and her gingival health became normal. We feel because of the retention of oil particles in her sub-gingival tissues her gingival health had worsened.

OP therapy has been shown to reduce plaque index ${ }^{1}$ as well as Streptococcus mutans count in plaque and saliva. ${ }^{2}$ We are of the opinion that until the benefits and indications for OP are documented and established scientifically it should not be recommended.

\section{N. Ravikumar}

S. Suhas

Tumkur

1. Asokan S, Emmadi P, Chamundeswari R. Effect of oil pulling on plaque induced gingivitis: a randomized, controlled, triple-blind study. Indian J Dent Res 2009; 20: 47-51.

2. Asokan S, Rathan J, Muthu M S et al. Effect of oil pulling on streptococcus mutans count in plaque and saliva using Dentocult SM Strip mutans test: a randomized, controlled, triple-blind study. J Indian Soc Pedod Prev Dent 2008; 26: 12-17.

DOI: $10.1038 /$ sj.bdj.1087

\section{TUBERCULOSIS DIAGNOSIS}

Sir, a 37-year-old woman was referred by her general medical practitioner with a two-month history of an increasing right-sided facial swelling. She has been resident in the UK for ten years with no history of cough, weight loss or recent travel. On examination, there was a 3 $\mathrm{cm}$ raised, fluctuant lesion on the lower border of the mandible (Fig. 1). The orthopantogram and chest X-ray were unremarkable. Computed tomography showed a cystic collection at level $1 b$. Fine needle aspiration proved inconclusive. An excisional biopsy showed tuberculous lymphadenitis. ${ }^{1}$ Persistent lymphadenopathy of over four weeks' duration in people other than white UKborn should be regarded as tuberculosis until proven otherwise. ${ }^{2}$

\section{Al-Hadad, A. Ujam, B. Speculand Birmingham}

1. Kokosali K, Lloyd R E. Tuberculous cervical lymphadenitis: an unusual case. Dent Update 2006; 33: 306-308, 311.

2. National Collaborating Centre for Chronic Conditions. Tuberculosis: clinical diagnosis and management of tuberculosis, and measures for its prevention and control. London: Royal College of Physicians, 2006.

DOI: $10.1038 / s j . b d j .1088$

\section{HELP TO QUIT}

Sir, tobacco use is one of the major preventable causes of health damage and death in India. It is estimated that tobacco will kill 6 million people annually from 2010, 80\% of which will happen in low and middle income countries like India. ${ }^{1}$ The most susceptible age for initiating tobacco use in India is during adolescence and early childhood with most users starting use before the age of 18 years, while some start as young as ten years. Studies show that if people do not begin to use tobacco during adolescence, there is a good chance they never will. Each day about 5,500 children in India start using tobacco and join about 5 million children under the age of 15 years who are already addicted to tobacco. Adolescent tobacco use is characterised by being driven by relationships, activities, positive and negative emotions and social ramifications while adult tobacco use is defined by nicotine dependence.

According to the Global Youth Tobacco Survey (GYTS) (2000-2004) including students from grades 8-10 in India, $17.5 \%$ were current users of tobacco in any form, 14.6\% were using smokeless 